\title{
Methods for Management of Eutrophication in Freshwater Ecosystems in Vojvodina
}

\author{
Zorica Svirčev' ${ }^{1}$ Svetislav Krstić ${ }^{2}$, Slobodan B. Markovic ${ }^{3 *}$, Jovan Plavša ${ }^{3}$, Lazar Lazićc ${ }^{3}$ \\ Received: April 2008 | Revised: September 2008 | Accepted: October 2008
}

\begin{abstract}
Many techniques are available for improvement of water quality within the body of reservoirs: artificial mixing and oxygenation, sediment removal, sediment aeration, sediment covering, phosphorus inactivation, biomanipulation (fish management), hydraulic regulation, algicides, light reduction, macrophyte control and ecoremediation.
\end{abstract}

Ecoremediation presents a sustainable use of natural and creation of artificial ecosystems for environmental protection and restoration with a special importance for the Vojvodina water ecosystems, due to their seasonal pollution patterns and overall lack of fresh water in Republic of Serbia.

ERM is already established as perspective long-term approach, utilizing natural processes and such that imitate natural processes, and systems in favour of the remediation of degraded ecosystems and environmental protection.

Key words: ecoremedation, eutrofication, freshwaters, Vojvodina.

\section{Introduction}

Eutrophication is generally understood to refer to enrichment of water systems by nutrients, notably nitrogen and phosphorus, and to the enhanced production of algal and higher plant biomass that the added nutrient loads stimulate (Reynolds, 1992). Normally, the eutrophication is natural phenomenon, but during the last 2 decades, the word 'eutrophication' has been frequently used to denote the artificial and undesirable addition of plant nutrients to waterbodies (Ryding, Rast, 1989).

Eutrophication is a process whereby water bodies, such as lakes, estuaries, or slow-moving streams receive excess nutrients that stimulate excessive plant growth (algae, periphyton attached algae, and nuisance plants weeds). This enhanced plant growth, often called an algal bloom, reduces dissolved oxygen in the water when dead plant material decomposes and can frequently cause other water biota (fish in particular) to die. Nutrients can come from many sources, such as: fertilizers applied to agricultural fields, suburban lawns, deposition of nitrogen from the atmosphere, erosion of soil containing nutrients and sewage treatment plant discharges. Eutrophication is "a kind of decreasing of the water quality" (Henry, 1993).
Accelerated eutrophication of water ecosystems, as a direct consequence of the rapid increase of human population, urbanization and modern agriculture practice, has apparently intensified the occurence of the toxic cyanobacterial blooms as well. In that sense, stagnant water ecosystems are especially vulnerable, including the drinking water supply reservoirs. Therefore, many techniques have been developed for improvement of the water quality in reservoirs. Some of them are listed in Table 1.

Hydrometeorological Department of Serbia is appointed instituion to monitor the water quality in 38 reservoirs, according to Government Program, once per year. Comparative analysis of the hitherto established hydrobiological investigations revealed that only a small number of reservoirs in Serbia have been covered by comlex investigations. Some of them include Đerdap, Gruža, Grošnica, Vlasina, Grlište, Barje, and some small reservoirs and lakes in Vojvodina (Borkovac, Zobnatica, Sot, Palić, and Ludoš). Hydrometeorological Department of Serbia has been monitored the water quality in 143 water flows in Serbia, 61 belong to Vojvodina region, according to Government Program, once per year. Nevertheless, even on these water bodies the investigations were mostly conducted in a specific and limited time period without comprehensive and continual mon-

\footnotetext{
Department of Biology and Ecology, Faculty of Science, Novi Sad, Serbia

2 Institute of Biology, Faculty of Natural Science, Skopje, Macedonia

${ }^{3}$ Department of Geography, Tourism and Hotel Management, Faculty of Science, Novi Sad, Serbia

* Corresponding author, e-mail: zbir@im.ns.ac.yu
} 
Table 1. Ecotechnological methods applied to reservoir watershed management and recovery (Straškraba, Tundisi, 1999)

\begin{tabular}{|c|c|}
\hline PROBLEM TO BE SOLVED & METHODS \\
\hline ORGANIC POLLUTION & $\begin{array}{l}\text { Clean production } \\
\text { Diversion of effluents } \\
\text { Purification plants }\end{array}$ \\
\hline EXCESS NUTRIENTS AND EUTROPHICATION & $\begin{array}{l}\text { Wetlands } \\
\text { Diversion of wastes } \\
\text { Tartiary treatment plants } \\
\text { Progressive agriculture practices } \\
\text { Meadow and riparian forest zones on the vegetated banks } \\
\text { Natural and constructed wetlands } \\
\text { Pre-impoundments at the inflows }\end{array}$ \\
\hline $\begin{array}{l}\text { EUTROPHICATION AND OXYGEN DEPLETION OF RIVERS } \\
\text { RESERVOIRS SILTATION }\end{array}$ & $\begin{array}{l}\text { Wahnbach P-reducton plant } \\
\text { River restoration } \\
\text { Re-oxygenation } \\
\text { Erosion control } \\
\text { Rehabilitation of river banks } \\
\text { Reforestation } \\
\text { Groundwater recharge } \\
\text { Pre-impoundment of inflows }\end{array}$ \\
\hline HEAVY METAL CONTAMINATION & $\begin{array}{l}\text { Reduction of polluted effluents } \\
\text { Wetlands }\end{array}$ \\
\hline ACIDIFICATION & $\begin{array}{l}\text { Liming } \\
\text { Organic matter additions }\end{array}$ \\
\hline SALINIZATION & $\begin{array}{l}\text { Improved irrigation practices } \\
\text { Decreased fertilizer applications } \\
\text { Decreased road salting }\end{array}$ \\
\hline DECREASED BIODIVERSITY DUE TO RESERVOIR CONSTRUCTION & $\begin{array}{l}\text { Prohibit introduction of foreign species } \\
\text { Reintroduction of native species } \\
\text { Maintenance of wetlands as nursery grounds } \\
\text { Maintenance of preserved areas for native species }\end{array}$ \\
\hline
\end{tabular}

itoring system. Gained results on the other hand were also not used properly in the management or exploitation activities (Gajin et al., 2003).

Through systematic investigations on Borkovac reservoir, Svirčev and Marković (1996) confirm the trend of significant water qaulity deterioration what resulted in a drastic shrinking of the waterbody. Sanation measures were also proposed which have not ever been implemented. In the last 10 years, detected rapid eutrophication processes in this reservoir have led to successive changes typical for swamps, having cyanobacterial "water bloom" episodes every year with marked presence of cyanotoxins in the water (Simeunović et al., 2005).

Water quality decreasing in Vojvodina has also been detected not only in reservoirs but in natural lakes, rivers and Danube-Tisza-Danube (DTD) channel system. Very comprehensive review on rapid water deterioration in Palić and Ludoš lakes and proposed sanation methods can be found in studies published by Seleši (2000) and Dulić (2002). Large rivers The Danube, The Sava, The Tisza and The Tamiš, and their tributaries are also more or less eutrophic. A good example is Ponjavica River in South Banat (now protected watercourse, Nature Park) which has lost a major portion of its flow to becoming a swamp, having frequent occurrence of small green algae in "water blooms" (Obušković, 1991). Comprehensive water analysis of The Tamiš River (Marković and Svirčev, 1998) reveiled rapid eutrophication stage and the imperative need for immediate sanation activities.
"Water blooms", or mass development of algae in the water, are the visible evidence of eutrophication in water ecosystems. Episodes of "water blooms" are very frequent in stagnant waterbodies in Vojvodina, but are also increasingly reported for our Planet as well. Most recent investigations (Svirčev et al., 2006) on 26 water ecosystems in Serbia point out the anxious fact that the water quality is rapidly deteriorating, what has been detected as the basic cause of Primary Liver Cancer (PLC) incresing in regions of Central Serbia where the drinking water supply systems are based on reservoirs with detected cyanobacterial "water blooms" (Svirčev et al., in press). Gruža reservoir is also confirmed eutrophic waterbody in which, apart of frequent "water blooms" of Aphanizomenon flos-aque, massive development of dinophytes (Pyrrophyta) have also been noticed (Ranković et al., 1994). Recent investigations by Svirčev et al. (2006) showed that the water quality in Celije, Bovan, Grliška, Gruža, Bukulja, Garaši, Borkovac, and Pavlovci reservoirs, and 20 other water ecosystms in Vojvodina were in such stage that accelerated eutrophication has been confirmed.

These findings are in compliance also with the recent investigations by Simeunović et al. (2005) who postulate the basic cause for increased cyanobacterial "blooms" and cyanobacterial toxin release in examined waters in accelerated eutrophication pattern in Vojvodina. Detected rapid eutrophication and water quality deterioration in investigated freshwater ecosystems in Vojvodina evidently demand rapid implementation of revitalization measures. 


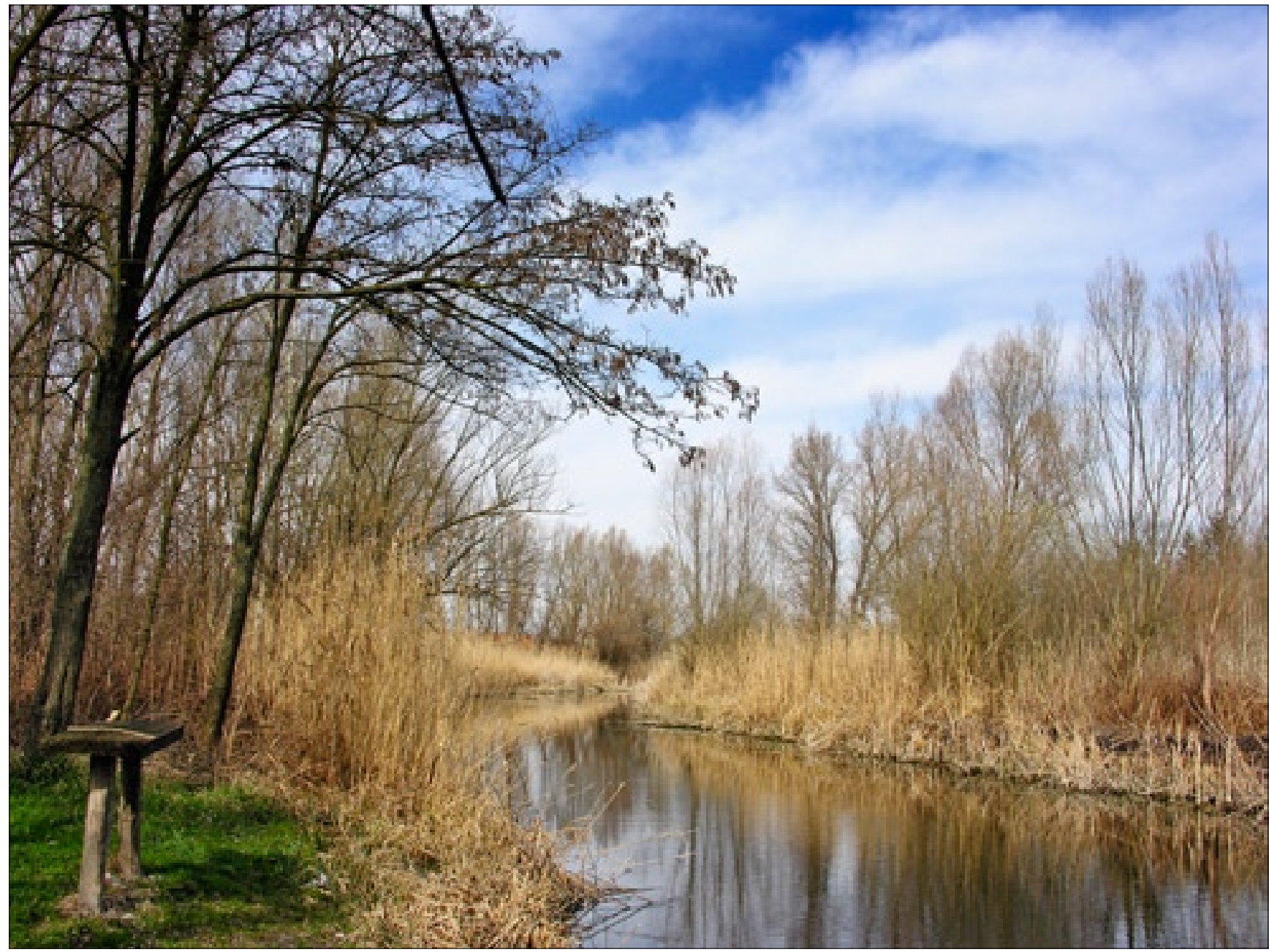

Figure 1 Natural ecoremediation in DTD channel Bezdan-Vrbas nearby the Sombor town (Vojvodina)

The principle aim of this paper is to present known reservoir sanation methods and to describe in more details the ecoremediation metod (ERM), one of the most recent method in the world still not implemented in water ecosystem sanation in Republic of Serbia.

\section{Management techniques for improving water quality in reservoirs}

Reservoirs have been predominantly built with respect to water quantity and the guarantee of sufficient water quantity is still the basic requirement of reservoir operation. However, water quality aspects are of increasing concern, because a growing number of reservoirs are used for water supply purposes and consequently the water quality being of legislative concern as well (Table 3 ).

\section{Mixing and oxygenation}

The aim of artificial mixing procedures is oxidation of either a deoxygeneted hypolimnion or the entire waterbody and/or inhibition of phytoplankton growth.

Destratification is accomplished by injection of compressed air from a diffuser into water at a reservoir bottom. These tree goals are simultaneously sought:

1. destratification to prevent algae from remaining in the illuminated layer and causing a decrease in phytoplankton biomass formation;
2. circulation to decrease $\mathrm{pH}$ and cause a shift from bluegreen to less noxious green algae;

3. aeration to oxidize the hypolimnion and consequently seal the bottom to prevent release of phosphorus, iron and manganese.

Undesirable consequences may result in some cases. Early examples of practical use of destratification are summarized by Pastorak et al. (1981) who reported that from out of 140 relatively full destratification attempts there was a significant change in biomass in 65 of the cases, of which $70 \%$ underwent a biomass decrease and $30 \%$ experienced an increase and were accompanied by changes in species composition. An air flow of oxygen has to surpass $0.09 \mathrm{~m}^{3} \mathrm{ha}^{-1}$, otherwise the mixing is inactive (Schladow, 1993). The advantages of destratification are as follows: hypolimnetic oxygen increases; there is no phosphorus release from the sediments; the amounts of iron and manganese remain low or absent; and the amount of algae decreases. Cost of the procedure is low.

Layer aeration is a relatively new approach that is based on detailed knowledge of stratification conditions in a given waterbody and the consequences of these in terms of water quality (Kortmann et al., 1988). Under this strategy, heat and oxygen in a stratified reservoir are redistributed into discrete layers. Manipulation of the thermal structure can create desirable physical and chemical conditions. In this 
Table 3. Management techniques for improving water quality in reservoirs (Straškraba \& Tundisi, 1999)

\begin{tabular}{|l|l|l|}
\hline MEASURE & MEANS & REFERENCES \\
\hline & $\begin{array}{l}\text { 1. Destratification } \\
\text { 2. Hypolimnetic aeration } \\
\text { 3. Epilimnetic mixing } \\
\text { ARTIFICIAL MIXING AND OXYGENATION } \\
\text { 5. Layer aeration } \\
\text { 6. Speece cone } \\
\text { 7. Propeller mixing }\end{array}$ & $\begin{array}{l}\text { Symons et al., 1967 } \\
\text { Bernhardt, 1967 } \\
\text { Straškraba, 1986 } \\
\text { Stefan et al., 1987 } \\
\text { Kortmann et al., 1994 } \\
\text { Speece et al., 1982 } \\
\text { Fay, 1994 }\end{array}$ \\
\hline SEDIMENT REMOVAL & Dredging the sediment & Bjork, 1994 \\
\hline SEDIMENT AERATION & Sediment injection & Ripl, 1976 \\
\hline SEDIMENT COVERING & Covering sediments with inert matter & Peterson, 1982 \\
\hline PHOSPHORUS INACTIVATION & Alum precipitation & Cooke \& Kennedy, 1988 \\
\hline BIOMANIPULATION (FISH MANAGEMENT) & $\begin{array}{l}\text { Zooplankton control - phytoplankton } \\
\text { reduction }\end{array}$ & Gulati et al., 1990 \\
\hline \multirow{2}{*}{ HYDRAULIC REGULATION } & $\begin{array}{l}\text { 1. Selective offtake and withdrawal } \\
\text { 2. Hypolimnion siphoning } \\
\text { 3. Curtains }\end{array}$ & Straškraba, 1986 \\
\hline ALGICIDES & $\begin{array}{l}\text { 1. Copper poisoning } \\
\text { 2. Other algicides }\end{array}$ & Olszewski, 1967 \\
\hline LIGHT REDUCTION & Shading, covering, suspensions, colors & \\
\hline MACROPHYTE CONTROL & 1. Harvest & 2. Phytophagus fish \\
3. Natural enemies & \\
\hline
\end{tabular}

way the negative effects previously mentioned that often accompany destratification are avoided.

\section{Methods of treating sediments}

Sediments accumulate phosphorus over long periods of time and the resulting concentrations of phosphorus in the upper few millimeters of the sediment can be much greater than the phosphorus content in the entire water column. The dissolved fraction of this large phosphorus store is constantly exchanged with the adjacent water. Because of the large phosphorus storage in the sediments, eutrophic conditions may continue for several years after phosphorus supply to the reservoir is considerably reduced. Various procedures are used to decrease the release of phosphorus from the sediments.

Sediment removal consists of the removing the upper layers of sediment that contain high phosphorus levels. Methods of sediment removal and their respective cost-effectiveness were reviewed by Peterson (1982). The advantage of this method is that the result are long lasting. In lake Trummen in Sweden, phosphorus concentration dropped from peaks as high as $900 \mu \mathrm{g} \mathrm{l}^{-1}$ to a level less that $10 \mu \mathrm{g} \mathrm{l}^{-1}$ and remained that low for the whole period of observations, which extended more than 9 years (Straškraba \& Tundisi, 1999; Seleši, 200o). The cost is high.

\section{Biomanipulation}

At the begining of the '6os, Hrbacek and co-workers (Hrbacek et al., 1961) drew attention to the existance of a topdown control of the food chain, of equal importance to bottom-up control (De Bernardi, Giussani, 1995).

A term "biomanipulation" was established by Shapiro et al. (1975). The principle of the method is food chain manipulation by maintaining low feeding pressure on zooplank- ton by fish, so that large species of zooplankton predominate, that are capable to keep phytoplankton under control. This is accomplished when the number of zooplankton feeding fish is low. Development of fish populations that lead to control of zooplankton and phytoplankton can be achieved by the following three ways:

1. temporary eradication of stunted fish populations by using rotenone poisoning and predator stocking (rotenone is non toxic for invertebrates and phytoplankton);

2. continuous introduction of predatory fish and net-harvesting of non-predatory fish; collaboration with local sport fishery and use of commercial fishery methods is needed;

3. reservoir drawdowns during reproduction periods of undesirable fish species by exposing eggs on shore vegetation.

The advantages of this method, aside from very low cost, is that it is fully natural, with no chemicals or machinery required; the only means used is manpower. Costs are low if combined with organized fisheries efforts but increase when these efforts are not combined (Straškraba, Tundisi, 1999).

Biomanipulation is a form of biological engineering in which organisms are selectively removed or encouraged to alleviate the symptoms of eutrophication. Most examples involve fish and grazer zooplankton though mussels have also been used (Jorgensen, 1992).

\section{Algicide use}

The addition of algicide such as simazine or copper sulfate has long been used as an emergency measure to control excessive algal growths. The dosage of $\mathrm{CuSO}_{4}$ application varies between $6 \mathrm{~kg}$ and $20 \mathrm{~kg} \mathrm{ha}^{-1}$, depending on the 
depth of the algal layer. A concentration of 1-2 $\mathrm{mg} \mathrm{l}^{-1}$ must be reached in order for the application to be effective. The only advantage of the method is that it works rapidly. The limitations include the short duration of effects. The method is not advisable because of its negative environmental impacts. $\mathrm{CuSO}_{4}$ is toxic to fish, zooplankton and other organisms.

In the area where $500 \mathrm{~kg} \mathrm{ha}^{-1}$ was applied, regrowth was not observed, indicating that this method is successful in eliminating benthic cyanobacteria. Copper sulphate not only had a great impact on the cyanobacteria, it appeared to be lethal for all living benthos at $500 \mathrm{~kg} \mathrm{ha}^{-1}$ and killed more than $50 \%$ at $250 \mathrm{~kg} \mathrm{ha}^{-1}$ (Gijsbert, Van Breemen, 1992).

\section{Ecoremediations (ERM)}

Ecoremediation is a system of utilizing the natural processes for revival, restoration and protection of the natural environment. ERM methods may reduce and avert the consequences of agricultural pollution, tourism, transport, industry, landfills and (over)population. In its essence, ERM represents the 'returning to nature' approach aiming to preserve or re-establish the natural balance of the ecosystems, but also a human endeavour that enables new jobs and by-side activities important for economic and social (sustainable) development of the human society.

The knowledge on the use of ecoremediation methods for wastewater treatment spread quite slowly during the 1970 s and the early 1980 os both in Europe and North America. In Europe, the knowledge spread mostly through the individual efforts of individual persons in institutions such as Max Planck Institute in Plön, Germany, University of Aarhus in Denmark or Water Research Center in Swindon, UK (Vymazal, 2006).

Thirty years of the research on the use of constructed wetlands as the most common ERM method for various types of wastewater has proven that the great number of early worries and negative arguments has been successfully denied. For example, it has been shown that constructed wetlands may perform well under cold climatic conditions (Mander, Jenssen, 2003). Also, constructed wetlands are commonly used in countries with high population densities, such as Denmark, Belgium or the Netherlands. The use of constructed wetlands for various industrial effluents is now also quite common.

Ecoremediation method in broader sense is applied by Vrhovšek (Vovk Korže, Vrhovšek, 2006) more than 20 years. The efficiency and genuinity of this idea has forced us in a more scientific, but also phylosophical approach which, we hope, will speed-up the practical implementation of ERM in Serbia.

Ecoremediation presents a sustainable use of natural and creation of artificial ecosystems for environmental protection and restoration with a special importance for the Mediterranean environment, due to its seasonal pollution patterns, and lack of fresh water (Vovk Korže, Vrhovšek, 2006).

Ecoremediation as a system for protection, sanation and remediation of the environment can be appreciated from very different stand points. Globaly, from the top, can be said that ERM is a buffer system that enables the re-estab- lishing of the disturbed ecological balance in its original position. As an immune system of our planet, ERM is the preventive defence that protects against the system being in not desirable modified stage. In general, ERM is consist of abiotic and biotic elements and processes that have a role in balancing the ecosystems.

If regarded as a method for imroving the quality of human lives, ERM means to give nature a chance to prevent and correct the human mistakes. In that sense, ERM is very close to the nature and humans, while technologicaly being quite a simple system. ERM is based on the principle of forcing the natural processes to most effectivelly revitalise the degraded parts of the environment. ERM is realized through a comprehensive approach in solving the problems via recognizing the natural mechanisms which are selectivelly steered to meet human needs. It is actually realized through congenial help for nature (ecosystems) aiming to solve the pre-detected problems. Anthropocentrically speaking, ERM represents establishing the balance among the elements of the new working system, made by man, as a sub-system model in altered defined conditions with elements of a specific process design and the development sustainability of the whole ecosystem.

\section{Why use ecoremediation?}

1. Efficient in purification;

2. It cost less (can be less than $10 \%$ to $75 \%$ of other approaches);

3. Simple in concept, inexpensive and easy to place in operation;

4. It can be a permanent solution;

5. No mechanical nor electrical equipment is needed;

6. Even if a breakdown occurs, it can be rapidly repaired;

7. High buffering capacity;

8. Water retention;

9. Plant materials are aesthetic pleasing and can actually increase soil fertility;

10.The plant materials can actually modify the underlying waste materials over time making the system environmentally friendly;

11. ERM units built as a part of the local environment-habitat creation;

12. Biodiversity.

\section{Possible Utilization}

- Remedy of long-term consequences of harmful human activities in the environment;

- Enhancement of disburdening and self-protective capabilities of habitats and running waters from non-point pollution sources;

- Remedy of seasonal pollution impacts, e.g. tourism;

- Tertiary or supplementary treatment of communal, stock farming, industrial and other harmful wastewaters;

- Conditioning of water for various uses (watering, irrigation, drinking water, retention basins, etc.);

- Protection of nature reserves;

- Protection of ground water, water points and other sensitive areas;

- Protection against polluted water discharges in lakes and the sea. 


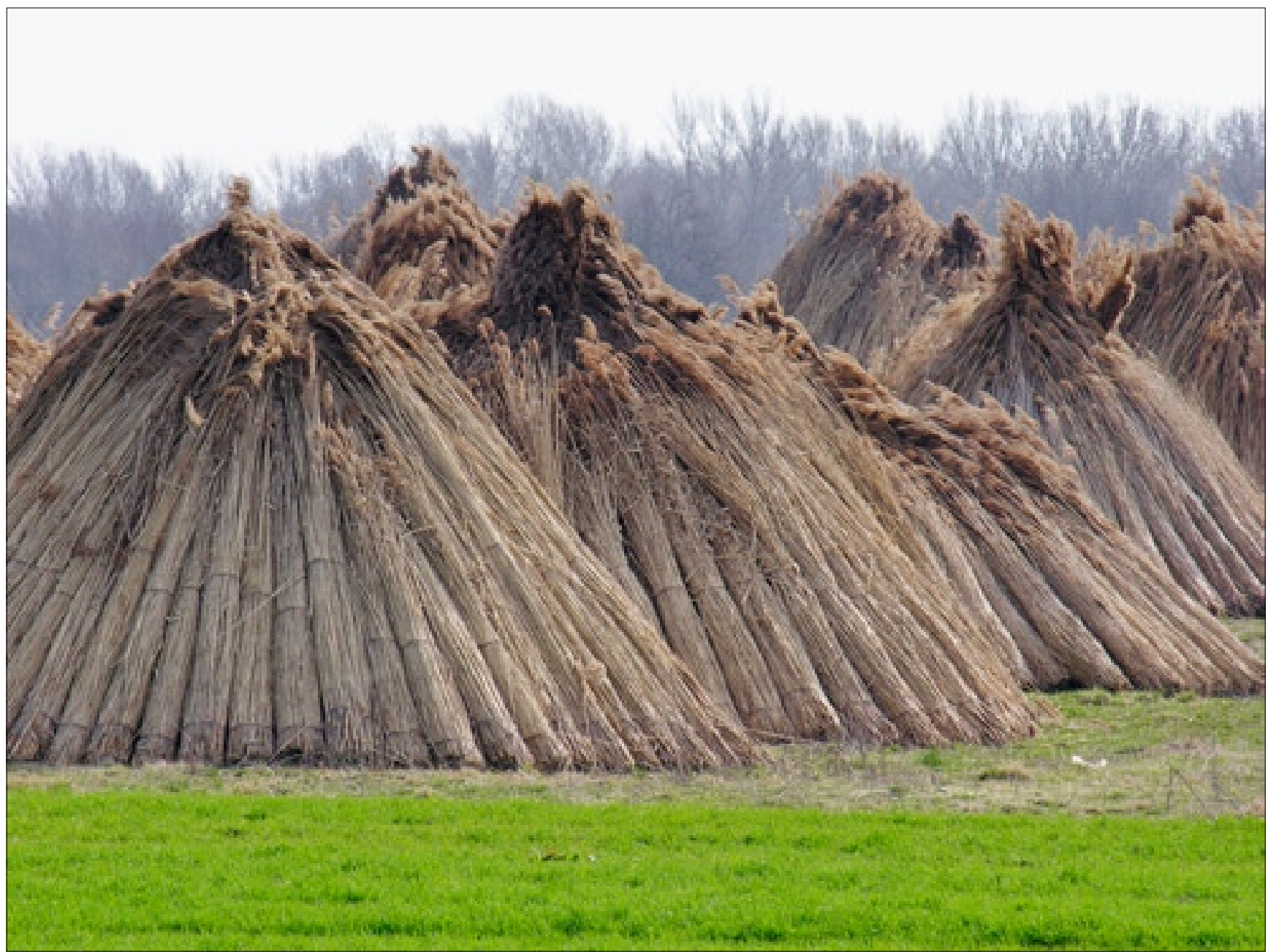

Figure $\mathbf{2}$ The utilization of macrophyte biomass in manufacture

ERM is already established as perspective long-term approach, utilizing natural processes and such that imitate natural processes, and systems in favour of the remediation of degraded ecosystems and environmental protection. In practice ERM are used as:

- plant purification systems,

- natural dumping sites sanation systems,

- near shoreline plant buffer belts-alleviation areas,

- side river water courses,

- artificial swamps,

- protective barriers aginst noise and dust,

- phyto-remediation of polluted sediments,

- constucting of rapids and cascades.

Constructed wetlands are widely regarded as low-cost alternatives for treating different types of wastewater. The usual applications of constructed wetlands are: secondary or polishing treatment of domestic sewage from rural communities; treatment of urban and agricultural runoff; treatment of agro food farm or industrial effluents and drying of sludge from sewage treatment plants. There are currently thousands of constructed wetlands throughout the world, but the use of these systems for treating wastewater is a relatively new technology in most countries.

Ecoremediation comprises systems and processes which function in natural and artificial ecosystems; it protects and restores the environment. It is comparatively inexpensive and highly efficient in protection of water resources, streams, rivers, lakes, groundwater and the sea. The basic characteristics of ERM, which can be utilized and improved, are its high buffer and self-protective capacities, and preservation of natural habitats and biological diversity (Vovk Korže, Vrhovšek, 2006). ERM is used for multipurpose management of watercourses, lakes and wetlands, which enables integrated development of particular areas and contributes to the coexistence of man and nature. Therefore, the ERM is among the most successful and sustainable methods of environmental protection, from the economic and ecological point of view (Vovk Korže, Vrhovšek, 2006).

\section{Conclusion}

Healthy environment is rapidly becoming very important value in human life and a criterion of the quality of living. To achieve this target, many of us consider the 'returning to nature' and respecting the ancient laws of nature as the ultimate solution.

Management techniques used for improving the water quality in reservoirs include: artificial mixing and oxygenation, sediment removal, sediment aeration, sediment covering, phosphorus inactivation, biomanipulation (fish management), hydraulic regulation, algicides, light reduction, macrophyte control and ecoremediation.

Ecoremediation is a system of utilizing the natural processes for revival and protection of the environment. ERM 
methods may reduce and avert the consequences of agricultural pollution, tourism, transport, industry, landfills and (over)population. In its essence, ERM represents the 'returning to nature' approach aiming to preserve or re-establish the natural balance of the ecosystems, but also a human endevour that enables new jobs and by-side activities important for economic and social (sustainable) development of the human society.

\section{Acknowledgements}

The authors acknowledge financial support of the European Community allotted by the European Agency for Reconstruction through the Ministry of International Economic Relations of the Republic of Serbia whithin the Neighbourhood Programme Hungary-Serbia (Action entitled "Regional Water Resources Investigations in the Scope of Sustainable Development", Grant No. 04SERo2/o1/oog).

\section{References}

Bernhardt, H. 1967. Aeration of Wahnbach Reservoir without changing the temperature profile. Journal of American Water Works Association 59, 943-964.

Bjork, S. 1994. Sediment removal. In: Eiseltova M.(Ed.) Restoration of Lake Ecosystems - a holistic approach. International Waterflow and Waterlands Research Bureau, Slimbridge, Gloucester, UK.

Cook, G.D., Kennedy, R.H. 1988. Water quality management for reservoirs and tailwaters. Report 2. In-reservoir water quality management techniques. Technical report, U.S. Army Engineer Waterways Experiment Station, Vickburg, Mississippi.

De Bernardi, R., Giussani, G. (Eds.) 1995. Guidelines of Lake management, Biomanipulation in Lakes and Reservoirs Management, Volume 7, ILEC. pp 215.

Dulić, S. 2002. Fitoplankton kao pokazatelj eutrofizacije Ludoškog jezera. Magistarski rad u rukopisu. Departman za biologiju i ekologiju PMF, Novi Sad.

Fay, F. M. 1994. Oxygenation and agitation of lakes using approven marine technology. Lake and Reservoir Management 9, 102-105.

Gajin, S., Čomić, Lj., Petrović, O., Matavulj, M. 2003. Hidroakumulacije i problem eutrofizacije vode. In: Ivanc, A., Miljanović, B. (eds.) Hidroakumulacije: multidisciplinarni pristup održivom razvoju. PMF, Novi Sad, 145-155.

Gijsbert, O., Van Breemen, L. 1992. Management of Biesbosch Reservoirs for quality control with special reference to eutrophication. In: Sutcliffe, D.W. \& Jones, J.G. Eutrophication: research and application to water supply. Freshwater biological association. pp 217.

Gulati, R.D., Lammens, E.H.R.R., Meijr, M.-L., van Donk, E.(Eds.) 1990. Biomanipulation - Tool for Water Management. Kluwer Academic Publishers, Dortrecht. pp 628.

Henry,W.A.(ed.) 1993. The Dictionary of Ecology and Environmental Science: Pownal, Vermont, Henry Holt and Company, Inc.

Hrbacek, J., Dvorakov, M., Korinek, V., Prochazkova 1961. Demonstration of the effect of the fish-stock on the species composition of zooplankton and the intensity of metabolism of whole plankton association. Verh. int. Ver. Limnol. 14, 192-195.
Jorgensen, S.E. 1992. Structural dynamic eutrophication models. In: Sutcliffe, D.W. \& Jones, J.G. Eutrophication: research and application to water supply. Freshwater biological association. pp 217.

Kortmann, R.W., Conners, M.E., Knoecklein, G.W. \& Bonnell, C.H. 1988. Utility of layer aeration for reservoir and lake management. Lake and Reservoir Management 4: 35-50.

Kortmann, R.W., Knoecklein, G.W., Rich, P.H. 1994. Aeration of stratified lakes: Theory and practice. Lake and Reservoir Management 8, 99-120.

Mander, Ü., Jenssen, P. (eds.) 2003. Constructed Wetlands for Wastewater Treatment in Cold Climates. WIT Press, Southampton, U.K.

Marković, S. B., Svirčev, Z. 1998. Naš Tamiš. Naučna monografija. Institut za geografiju, PMF, S. B. Marković and Z. Svirčev, eds. Novi Sad. pp. 172.

Obušković, Lj. 1991. Fitoplankton i saprobiološke karakteristike kao pokazatelj ubrzane eutrofizacije reke Ponjavice (Južni Banat). Zbornik radova konferencije „Zaštita voda '91', 333-337.

Obušković, Lj. 2003. Fitoplankton - primarna produkcija i eutrofizacija. In: Ivanc, A., Miljanović, B. (eds.) Hidroakumulacije: multidisciplinarni pristup održivom razvoju. PMF, Novi Sad, 186-195.

Olszewski, P. 1967. Die Ableitung des hypolimnischen Wassers aus einem See. Mitt blat Fed. Europ. Gewasserschutz 14, 87-89.

Pastorak, R.A., Ginn, T.C., Lorenzen, M.W. 1981. Evaluation of aeration/circulation as a lake restoration technique. $\mathrm{U}$. S. Environmental Protection Agency, EPA, Washington D.C.

Peterson, S.A. 1982. Lake restoration by sediment removal. Water Research Buillten 18, 423-435.

Ranković, B., Čomić, Lj., Simić, S. 1994. Fitoplankton i saprobiološke odlike akumulacije Gruža u 1992. godini. Zbornik radova konferencije "Zaštita voda ' 94 “, 110-115..

Reynolds, C.S. 1992. Swings and roundabouts: engineering the environment of algal growth. In Urban Waterside Regeneration. Simon \& Schuster, Chichester.

Ripl, W. 1976. Biochemical oxidation of polluted lake sediment with nitrate - a new lake restoration method. AMBIO, 5: 132-135.

Ryding, S.O., Rast, W. 1989. The Control of Eutrophication of Lakes and Reservoirs. Man and Biosphere Series by UNESCO, Volume I. Paris and the Parthenon Publishing Group.

Schladow, S.G. 1993. Lake destratification by bubble plume systems: A design methodology. J. Hydraulics Engng Div., ASCE, 119: 350-368.

Seleši, Đ. 200o. Voda Palićkog jezera od 1781. do 1999. PalićLudaš, Subotica.

Shapiro, J., Lamarra, V., Lynch, M. 1975. Biomanipulation, an ecosystems approach to lake restoration. In: Brezonik, P.L., Fox, J.L. (Eds.) Proc. Symp. Water Quality Management Through Biological Control. Univ. Florida Press, Gainesville, Florida: 85-96.

Shapiro, J.H., Wright, D.I. 1984. Lake restoration by biomanipulation: Round Lake, Minnesota, the first two years. Freshwater Biology 14, 371-383. 
Simeunović, J., Svirčev, Z., Krstić, S., Lazić, L. 2005. Occurrence of cyanobacterial blooms in Vojvodina water ecosystems. Geographica Pannonica 9, 13-19.

Speece R.E. et al. 1982. Hypolimnetic oxygenation studies in Clark Hill Lake. J.Hyadraulics Engng. Div., ASCE, 108: 225-244.

Stefan, H.G., Bender, M.D., Shapiro, J., Wright, D.I. 1987. Hydrodynamic, design of a metalimnetic lake aerator. J. Environm. Engng. Div., ASCE, 113: 1249-1264.

Straškraba, M. 1986. Ecotechnological measures against eutrophication. Limnologica 17, 239-249.

Straškraba, M., Tundisi, J.G. (Eds.) 1999. Guidelines of Lake management, Reservoir water quality management 9 , ILEC. pp 229.

Svirčev, Z., Krstić, S., Simeunović, J., Nakov, T., Dulić, T. 2006. Comparative analysis of water quality methods for the monitoring of eutrophication regarding implementation of WFD in Serbia. Geographica Panonica 10, 32-42.
Svirčev, Z., Marković, S. 1996. Akumulacija Borkovac, limnološka monografija. Skupština opštine Ruma, Ruma. pp 48.

Svirčev, Z., Simeunović, J., Krstić, S., Miladinov-Mikov M., Vidović, M. (in press): Freshwater cyanobacterial blooms and primary liver cancer epidemiological studies in Serbia.

Symons, J.M., Irwin, W.H., Clark, R.M., Roebeck, G.G. 1967. Management and measurment of DO in impoundments. J. Sanit. Engng. Div., ASCE, 93:181-209.

Vovk Korže, A., Vrhovšek, D. 2006. Ecoremediations for effective environmental protection. Environmental Institute, Maribor, pp. 56.

Vymazal, J. 2006. Constructed wetlands with emergent macrophytes: from experiments to a high quality treatment technology. Proceedings of 1oth International Conference on Wetland Systems for Water Pollution Control, September 23-29, 2006 Lisbon, Portugal, Vol.I, pp. 3-29. 